\title{
How Mixed-Ability Grouping Works in Botswana's Schools?
}

\author{
Jane Iloanya \\ Botho University
}

\begin{abstract}
Botswana was one of the countries (of the world) that signed at the Jomtein Conference of 1990 to provide equal access to education for all citizens of their countries. Botswana's Revised National Policy on Education (RNPE, 1994 and Vision 2016(1997) emphasised on the need to provide equal access to education for all children, including those with special needs. This paper focuses on how mixedability classes work in Botswana schools especially at the basic education level. It examines how teachers attend to learners with learning difficulties. The paper goes on to show the strides that the Botswana Government has made in catering for mixed ability groups in the educational system and efforts being made to ensure the effectiveness of "mixed-ability" teaching at the basic education level. Every child has the potential to learn and succeed in life. It is therefore the responsibility of the effective and efficient teacher to bring out the best in the children he/she teaches.
\end{abstract}

"There is nothing more unequal than the equal treatment of unequal people" -Thomas Jefferson

\section{Introduction}

Inclusive education is taking a very prominent stance in education in the $21^{\text {st }}$ century. It is a reform of the education system geared towards creating an education system that is responsive to learner diversity, ensuring that all learners have the most convenient possible opportunities to learn. Inclusive education ensures that all children in the neighbourhood attend the same regular school and classroom, regardless of their individual differences in learning, health, social and economic background [4] [5]. Inclusive education approach creates an education system that enrols maximum number of children with disability in the educational system. It enables school children to receive appropriate quality education and assists them to attain their innate potential, regardless of their physical and economic condition, gender and learning needs. The aim of inclusiveness in education, is to create an enabling environment where all learners receive education in a non-restrictive environment. Unfortunately, hundreds of millions of persons with disabilities do not have access to the opportunities and resources to afford basic human needs. They need access to education, to help alleviate poverty amongst the disabled people of the world.

Botswana is one of the countries in Africa actively involved in the promotion of education for children with special needs. Botswana's Revised National Policy on Education (RNPE) clearly states that the government is fully in support of education for all children, including those with special needs.

In pursuance of the above, special schools or research centres have been built to show government's commitment toward helping children with special needs. Teacher training and University curricular have been modified to include awareness courses in special needs education. Botswana's private institutions of higher learning, primary and secondary schools have special needs departments where children with learning difficulties are given special assistance, to enable them cope with the challenges of being in the same schools with the 'gifted' children.

This study sets out to examine the phenomenon of inclusion in Botswana schools and the teaching of students with learning difficulties at the basic education level. Basic education in Botswana covers the first ten-year period of education, starting from seven years of primary education to three years of junior secondary schooling. The government of Botswana provides free basic education to all children and they are all given the opportunity to attend school, regardless of their learning abilities. This study aimed at finding out the role of teachers in the management of students with learning difficulties. It focussed on the management of 'slow learners' when put in the same learning and teaching environment with 'fast learners' or academically 'gifted' students.

The effectiveness of 'mixed ability' teaching formed an integral part of this research. My research focused on pertinent questions such as:

i. How do teachers handle students with special needs?

ii. Are they motivated or demotivated by the teaching and learning environment? 
iii.Does mixed-ability teaching yield good results?

A conclusion is drawn by summarising the main themes that emerged from the study.

\section{Inclusive Education in Botswana}

Inclusive education in Botswana has received strong recognition and support by the government. Both the Revised National Education Policy and Botswana's vision 2016 stressed the need for all children to be provided with access to education. Since the Jomtien Conference of 1990, Botswana has actively participated in all international deliberationsons Education for All (EFA).Following the Jomtein Conference of 1990 where the right to education for all groups of children became a more burning international issue, some legislations were passed to support inclusive education. Among the principal legislations, are the UN Convention on the Rights of Persons with Disabilities, Flagship Initiatives, the World Declaration for Education for All Standard Rules on the Equalization of Opportunities of Persons with Disabilities, Salamanca Statement and Framework for Action, Dakar Framework for Action, and Millennium Development Goals.

Between the conferences of Jomtein and Dakar, was the Salamanca World Conference on Special Needs Education of 1994. Although the Salamanca statement is one of the international documents influencing inclusive education, its influence remains confined to the 'special needs' fraternity. Regrettably, the documents tend to be widely recognised in the wider context of Education for All. That notwithstanding, the importance of Salamanca in the design and implementation of educational programmes to recognise the diversity in the educational characteristics and special needs of the children cannot be overemphasised.Following the promulgation of the Revised National Policy on Education in Botswana, a Presidential Task Group was established in 1997 to come up with a long-term vision for the country. The outcome was the adoption of a report entitled 'Vision 2016: Towards Prosperity for All [5]. The main goals of the national vision, which include building an educated and informed society, fully subscribe to the philosophy, aims and objectives of the education policy. At the core of the Vision for the future,is the issue of improvements in the relevance, quality and access to education, which includes education for people with special needs.

It is estimated that, about 10-15 percent of school going age pupils in Botswana are still not in schools.
Most of these children are those with disabilities, learning difficulties, street children, child labourers, orphans, remote area dwellers, and those from poor families [6]. Subsequently, the Ministry of Education has developed policies and programmes aimed at ensuring that education opportunities are availed to all children of Botswana. The policy also promotes the integration of the disabled children in ordinary schools and the community at large.

In Botswana, Inclusive curriculum is the curriculum that is made accessible to all learners, regardless of their ability, sex, ethnicity, colour or creed. This curriculum has interconnected components such as curriculum design, language of instruction, selected content, teaching/learning approaches and instructional support materials that cater for learners of diverse socio-economic and cultural contexts [6]. The Curriculum Development Division of the Ministry of Education and Skills Development has adopted a universal design of learning (UDL) which offers differing activities that cater for learners of different abilities. At the primary school level the curriculum model uses a spiral approach which allows for constant revision and a gradual development of concepts. This approach makes it possible for both slow, average, and fast learners to be catered for during implementation at the classroom level. One principal element that affects the inclusiveness and non-inclusiveness of a curriculum is the content to be taught in the school subjects. To ensure a balanced selection of content, the curriculum in Botswana is developed through broad based national panels, where individuals or representatives of stakeholder institutions are selected from different parts of the country. The diverse national representation allows for the promotion of inclusion in the education system.

From the foregoing, it can be gleaned that government policies in Botswana are geared towards promoting inclusion in the education system. Government spends a lot of money to ensure that education is accessible to all children in the country, including those with special needs. There is free basic education in Botswana, and there are no restrictions in terms of admission criteria. From the primary to the junior secondary level in government owned schools (public), automatic progression is allowed. The main purpose of this, is to make sure that the citizens of Botswana receive free Education for All (EFA) and to enable them grasp reading, writing, and numeracy skills.

One of the major problems facing policy making in Africa, is the issue of implementation. Government has put in place policies to ensure that inclusive education is promoted in Botswana. Problems often arise when it comes to implementation. Are teachers 
ready to teach mixed-ability classes efficiently and effectively? Are teachers psychologically and emotionally prepared to face the challenges of teaching mixed- ability students? Do teachers receive training in the management of mixed-ability classes? These are some of the pertinent questions that my research will try to address.

\section{Methodology}

This is a qualitative research, which specifically focused on the phenomenon of mixed-ability teaching using, inclusive education. The qualitative approach of the phenomenological interpretative type was used to understand how the respondents will give meaning to and interpret the phenomenon which is being studied from their own subjective position. Qualitative research offers opportunities for conducting exploratory and descriptive research that assumes the value of context and setting and also allows the researcher to experience a deeper understanding of the participants [10] [12]. For a study of this nature, a qualitative research approach was considered appropriate because it allows for an in-depth and detailed description of events. It uses the natural setting as the source of data, thereby enabling the researcher to observe, describe and interpret settings as they are, maintaining an "emphatic neutrality" [8] [13].

The qualitative research method made it possible for me to act as the "human instrument" of data collection. For this study,I used semi-structured interviews to collect data from teachers of mixedability classes. Relevant literature from books and journal articles were used to augment the data. A total of ten participants were involved in the data collection process. Four primary school teachers, 4 junior secondary school teachers, and two senior members of staff from the special education department of the Ministry of Education in Botswana were interviewed. The interview questions were related to the issue of mixed-ability teaching at the basic education level in Botswana. The purpose of the interview was to find out how teachers handle teaching and learning in a mixed-ability set up; to determine if teachers motivate or demotivate students in mixed ability classes; and if mixed-ability teaching yields good results or not.

\section{Findings}

Findings from the research indicated the different ways the interviewees felt about mixed-ability classes in Botswana. The responses of the different categories of teachers were found to tally, even though there were some minor differences. The themes that emerged from the study are discussed under the following sub-headings:

\subsection{Handling students with special needs in a mixed-ability class}

Children with learning difficulties constitute a great percentage of handicapped children within the school system [1]. In Botswana, with the introduction of separate community junior schools in the early 1980 s and the issue of automatic promotion from primary to junior secondary schools, the problem of handling mixed-ability classes came to the fore. Children with learning difficulties abound at the basic education level in Botswana schools. The reason for this is not far-fetched. The 1990 Jomtien Conference, which emphasised on giving equal education opportunities to all children, made it imperative for the participating countries to give equal and open access to education. Botswana was one of the countries that signed the Jomtien Agreement of 1990.

The teachers that I interviewed stated categoricallythat, there are many loopholes and challenges in teaching mixed-ability classes. As the name implies, mixed ability means that there are individual differences in the learning abilities of the pupils at the primary school and junior secondary levels in Botswana. In a class of about forty students, there are the fast, average, and slow learners. Regrettably, most teachers teach average and fast learners, then the slow learners suffer and miss out a lot. One of the interviewees lamented that: "Teachers' learning and teaching objectives/outcomes indicate that, most teachers do not cater for all groups of learners. Some teachers recognise only fast learners." Even when some teachers put students in groups, they think about the teaching resources, not the abilities of the students, which affects the effective handling of children with learning difficulties in mixed-ability classes. In classroom discussions, some teachers focus more on the fast learners, and give names to the academically weak ones.

Worse still, some instructional materials used by teachers do not cater for the abilities of all the students in the actualisation of the intended learning outcomes. While stressing the effects of teachers' attitudes towards inclusion, Avramidis and Norwich state that, this could probably be due to limited or non-existent training for teachers to acquire integration competencies in certain countries [2]. Vaughan et al attribute some teachers' difficulties in handling mixed ability classes to class size, 
inadequate resources, and lack of adequate teacher preparation [16]. In support of the above, some teachers that I interviewed stressed the fact that they teach between 35 to 40 students in their classes. Unfortunately, in some schools, the academically weak students constitute the majority in these classes. One of the interviewees disclosed: "Initially, I found it difficult to teach mixed-ability classes, especially because of the automatic progression system from primary to junior secondary level in Botswana"

The interviewees, however, admitted they had to devise some coping mechanisms to be able to help the students. One might therefore concur with Avramidis that teachers' negative or neutral attitudes at the beginning of an innovation such as inclusive education may change over time, as a result of experience and the expertise that develops in the implementation process [2].

\subsection{To mix or not to mix?}

All classes are to some degree, made up of learners who differ in many ways [11]. The students may have different strengths, weaknesses, and approaches to learning. They may also react differently to various teaching methods and learning environments. Inclusive education takes cognisance of the fact that all children can learn. Mixed ability grouping involves an enabling environment and respect for differences in children, while the education systems employ methodologies to meet the needs of all children. It is about restricting the cultures, policies and practices in our schools to respond to the diversity of students in the locality. No child should be left behind, irrespective of the academic capabilities.The interviewees shared different opinions on the effectiveness and efficiency of mixed ability teaching. Some believe that the slow learners retard the progress of fast learners in mixedability classes. In Botswana, where there is automatic progression from primary to junior secondary schools, sometimes, the average and slow learners constitute the majority of the class size. Some of these slow learners are really slow, while some could improve, with proper learning support from the teachers. Some teachers complain that, they have a syllabus to cover and it becomes difficult with the pace of the slow learners; some weaker students relax and do not even try; the weaker students sit at the back and distract the stronger ones; the stronger students get bored, and demotivated; and sometimes, when a good number of the students have finished their class work, others are yet to finish.

There are many challenges faced by teachers of mixed-ability classes. Ur states that teachers may experience problems of discipline in their mixedability classes when learners feel frustrated, lose concentration, or get involved in disruptive behaviour, because of individual differences among them [15]. In mixed-ability classes, it may be difficult to provide effective learning for all the children, because the fast learners may find the content too simple, while the slow learners might find the same content very difficult. Again, interest may differ in their different learning styles and approaches, and the rate at which they get intrinsically or extrinsically motivated. When teachers do not give equal amount of opportunities to all learners to participate in class discussions in the mixed ability classes, the situation can pose some serious challenges in the management of mixed ability classes.

Despite the challenges of teaching mixed-ability classes, some of the interviewees stated that they do not mind teaching mixed-ability classes, because of the advantages that come with it. Mixed-ability classes give the teachers and the learners the opportunity for different types of learners to come together and share ideas. Every learner is special in one way or the other. They come to class with different knowledge, attitudes, aptitudes, ideas, experiences and interests, which can contribute to an interesting and interactive learning experience. Mixed-ability classes provide opportunities for teachers to develop themselves professionally, as they devise different problem solving approaches to the difficulties they face and test many teaching approaches and methodologies [14] [15]. The fact is that, a mixed-ability class relies heavily on the expertise of the teacher in helping a wide range of pupils to achieve their potential [7].

\subsection{How Mixed-Ability Grouping Work?}

Mixed-ability grouping can be promoted if the policy makers do some important ground works to make it positively practicable. Education policies should address the needs of all educationally disadvantaged groups in the society. Access to education should be made available to all children irrespective of gender, age, learning difficulties and cultural backgrounds. Policy makers should plan for schools which will educate all children together, and school systems should accept responsibility for children's learning, by availing the methodologies that are relevant and cater for different children's needs. The learning environment should be made conducive for all children to participate equally and fully during lessons. The teachers should accommodate the individual differences of the 
children and make every child feel special in his/her own way. The curriculum and the assessment system should be flexible and relevant to the individual needs and abilities of the children.

\section{Conclusion and Recommendations}

All schools at the basic education level in Botswana are mixed-ability schools. The government of Botswana is fully in support of education for all children, including those with special needs. The findings of my study indicate that teachers have mixed feelings about mixed-ability classes. Unlike some teachers who handle mixed-ability classes with positive attitude and acceptance, some teachers feel that, the government should stream students according to their abilities in order to make teaching and learning worthwhile for both teachers and the 'gifted' children. In mixed ability classes, there is the danger that the more able might not be stretched enough, while the less able are neglected.

Based on the above, the following recommendations are made to help mixed-ability teachers attain the desired learning outcomes. Teachers need to be aware that a class is mixedability because children have different strengths and weaknesses and develop at different rates. They have different preferences and styles for learning and displaying their work. A teacher should create a supportive learning environment in the classroom, where learners are recognised as individuals with differences in abilities. This will boost their confidence and help them perform to the best of their ability.

Teachers should use good classroom management techniques to enable all categories of learners to be actively involved in the learning process. Students should be positively motivated through praise and encouragement, giving good instructions, knowing students names, monitoring their activity and giving timely and constructive feedback.

Learners should be allowed to work in groups and the lessons should be highly interactive to give every learner a fair chance to participate.

Learners should be taught how to be creative and resourceful. Every learner is special in one way or the other. Slow learners should be given special attention to boost their self esteem

Teachers should make their lessons interesting by varying the activities and methodologies of instruction. A boring class is not good for either fast, average, or slow learners.

Every child can learn, regardless of the challenges that the child encounters, therefore,teachers need to diagnose and find out where the learner excels and encourage him/her to reach his/her potential.

\section{References}

[1] Abosi, C.O. \& Kandji-Murangi, I. (Eds)(1996). Education in Botswana: A reading text. Gaborone: Macmillan Botswana Publishing Co.

[2] Avramidis, E., Bayliss, P., \& Burden, R. (2000). Inclusion in action: an in-depth case study of an effective inclusive secondary school in the South-West of England. International Journal of Inclusive Education, 6, 38-43.

[3] Botswana, Republic of. (1990). Improving the quality of basic education in Botswana. Gaborone: Ministry of education.

[4] Botswana, Republic of. (1994). The revised national policy on education. Gaborone: Government Printers.

[5] Botswana, Repubic of. (1997). Vision 2016: Presidential task group for a long term vision for Botswana. Gaborone: Government Printers.

[6] Botswana, Republic of. (2008). National Report on Development of education: Inclusive education. Gaborone: Government Printers.

[7] Bremner, S. (2008). Some thoughts on teaching a mixed ability class. Scotish Languages Review, 18, 1-10.

[8] Chilisa, B., \& Preece, J. (2005). Research methods for adult education in Africa. Cape : CTP book printers.

[9] Friend, M. (2007). Special education contemporary perspectives for school professionals. New York: Pearson.

[10] Jurs, S.G., Wiersma, W. (2009). Research methods in education. Boston: Pearson.

[11] Ma, G. (2014). Wits Language School. Retrieved July 09, 2014, from Teaching Tips - Mixed Ability Classes: http://www.witslanguageschool.com/NewsRoom/ArticleVi ew/tabid/180/ArticleId/58/Teaching-Tips-Mixed-Ability-

Classes.aspx

[12] Marshall, W., \&Roseman, G. B. (1995). Designing qualitative research. Thousand Oaks CA: Sage.

[13] Patton, M.Q. (1990). Qualitative education and research methods. Thousand Oaks, CA: Sage.

[14] Tomlinson, C. (1999). The differentiated classroom: responding to the needs of the learners. Alexandra: ASCD. 
International Journal of Technology and Inclusive Education (IJTIE), Special Issue Volume 1, Issue 3, 2014

[15] Ur, P. (1991). A course in language teaching. Cambridge: Cambridge University Press.

[16] Vaughn, J., Schumm, J., \& Samuel, L. (1996).

Teachers' views of inclusion. Learning Disabilities Research and Practice, 11, 96-106. 